\title{
Bilateral Nonsynchronous Male Breast Cancer: Two Case Reports
}

\author{
Yoshiya Horimoto $^{a}$ Mako Hino ${ }^{a}$ Mitsue Saito ${ }^{a}$ Atsushi Arakawa ${ }^{b}$ Toshiharu Matsumoto $^{b}$ \\ Fujio Kasumia \\ a Department of Breast Surgical Oncology, \\ ${ }^{b}$ Department of Pathology, Juntendo University School of Medicine, Tokyo, Japan
}

\section{Key Words}

Male breast cancer - Bilateral · Aromatase - Testosterone . Adjuvant treatment

\section{Summary}

Background: Bilateral male breast cancer $(\mathrm{MBC})$ is relatively rare. Case Reports: We report 2 bilateral nonsynchronous MBC cases. Second cancers developed during endocrine therapy with selective estrogen receptor modulators (SERM) after the initial surgeries. Since their second surgeries, both patients continued treatment with another SERM, because their second cancers were also hormone receptor-positive. We discuss the endocrine therapy in men based on a review of the literature. Conclusions: Adequate treatments for early $\mathrm{MBC}$ are still controversial. Aromatase inhibitors (Al) are not as effective in men as in women. We consider the higher androgen levels in men to be a major reason for Al not being as effective as expected, i.e. the hormonal environment is very different from that in women. Thus, different approaches are needed for MBC. With further investigation, it is hoped that methods of achieving maximal Al efficacy for MBC will be established.

\section{Introduction}

Bilateral male breast cancer (MBC) is relatively rare. Although there are few reports on bilateral nonsynchronous

\section{Schlüsselwörter}

Brustkrebs beim Mann · Beidseitig · Aromatase .

Testosteron - Adjuvante Therapie

\section{Zusammenfassung}

Hintergrund: Beidseitiger Brustkrebs beim Mann ist relativ selten. Fallbericht: Wir stellen 2 Fälle von beidseitigem metachronen Brustkrebs beim Mann vor. Während der endokrinen Behandlung mit selektiven Östrogen-Rezeptor-Modulatoren (SERM) im Anschluss an die erste Operation kam es zu einem Wiederauftreten der Tumoren. Auch nach der zweiten Operation setzten beide Patienten die Behandlung mit anderen SERM fort, da die Rezidive ebenfalls Hormonrezeptor-positiv waren. Diese Studie behandelt unter Berücksichtigung der bestehenden Literatur die endokrine Therapie bei Männern. Schlussfolgerungen: Die angemessenen Behandlung von primärem Brustkrebs beim Mann wird weiterhin kontrovers diskutiert. Aromatase-Hemmer (Al) sind bei Männern nicht so wirksam wie bei Frauen. Wir nehmen an, dass höhere Androgenlevel, d.h. die Unterschiede im Hormonhaushalt von Mann und Frau, bei Männern die Hauptursache für die verringerte Wirksamkeit von Al ist. Dementsprechend ist im Falle von Brustkrebs beim Mann ein anderer Ansatz notwendig. Es ist zu hoffen, dass durch weitere Forschung Methoden gefunden werden, die eine optimale Wirksamkeit von Al bei Brustkrebs beim Mann erzielen.

MBC, bilaterality itself apparently has no prognostic significance. We describe 2 cases of bilateral MBC. Second cancers developed during hormonal therapy after the initial surgeries. We also discuss endocrine treatments for MBC.

\begin{tabular}{ll}
\hline KARGER & ○ 2008 S. Karger GmbH, Freiburg \\
$\begin{array}{l}\text { Fax +49 7614520714 } \\
\begin{array}{l}\text { E-mail Information@Karger.de } \\
\text { www.karger.com }\end{array}\end{array}$ & $\begin{array}{l}\text { Accessible online at: } \\
\text { www.karger.com/brc }\end{array}$ \\
&
\end{tabular}

Yoshiya Horimoto, M.D.

Department of Breast Surgical Oncology,

Juntendo University School of Medicine

2-1-1 Hongo, Bunkyo-ku, Tokyo, 113-0033, Japan

Tel. +81-90 3692 6031, Fax -3 38133307

E-mail arsenal_4_cesc@yahoo.co.jp 
Table 1. 8 cases of male breast cancer in our institution

\begin{tabular}{lllllll}
\hline Case & Age, years & $\begin{array}{l}\text { Pathologic } \\
\text { type }\end{array}$ & Nodal status & ER & TNM stage & $\begin{array}{c}\text { Adjuvant } \\
\text { therapy }\end{array}$ \\
\hline 1 & 67 & IDC & negative & positive & I & TAM \\
2 & 71 & IDC & negative & positive & I & TOR \\
3 & 62 & IDC & negative & positive & I & TAM \\
4 & 64 & IDC & negative & positive & I & TOR \\
5 & 75 & IDC & positive (1 node) & positive & IIA & CE, TAM \\
6 & 72 & IDC & negative & positive & I & TAM \\
7 & 59 & DCIS & negative & positive & 0 & none \\
8 & 64 & IDC & negative & positive & IIA & none \\
\hline
\end{tabular}

$\mathrm{ER}=$ Estrogen receptor; $\mathrm{TNM}=$ tumor-node-metastasis classification system of the International Union Against Cancer; IDC = invasive ductal carcinoma; TAM = tamoxifen; TOR = toremifene; $\mathrm{CE}=$ Cyclophosphamide and epirubicin. ${ }^{\mathrm{a}}$ Only sentinel lymph node biopsy was done.

\section{Case Reports}

Case 1

A 67-year-old man discovered a lump in his left breast. He came to our hospital after excisional biopsy showed breast cancer at another facility. He had a history of stomach cancer (stage IA), treated operatively, 1 year earlier. A modified radical mastectomy was performed. The histopathological findings indicated an invasive ductal carcinoma measuring $20 \mathrm{~mm}$ in diameter. Lymph nodes were free of metastasis (stage I). He was treated with tamoxifen (TAM) because the tumor was hormone receptor-positive. After 47 months of follow-up, a tumor was detected in his right breast by computed tomography. The patient underwent a modified radical mastectomy after confirmation of the breast cancer diagnosis by fine needle biopsy. Histological examination revealed an invasive ductal carcinoma measuring $18 \mathrm{~mm}$ (stage I), with ductal carcinoma in situ (DCIS). As we suspected an inadequate response to TAM, postoperatively, therapy was switched to toremifene (TOR). The patient has remained free of residual or metastatic disease for 27 months (10/2007) since the diagnosis.

\section{Case 2}

A 62-year-old man found a lump in his right breast. Breast cancer was diagnosed by excisional biopsy at another hospital. The patient underwent a modified radical mastectomy at our hospital. Histopathologically, the tumor, an invasive ductal carcinoma, measured $10 \mathrm{~mm}$ in diameter. There was no lymph node metastasis (stage I). He was treated with TAM because the tumor was hormone receptor-positive. After 19 months of follow-up, the patient found 2 lumps in his left breast. He underwent a modified radical mastectomy after fine needle biopsy confirmation of breast cancer. The histopathological diagnosis was invasive ductal carcinoma ( 8 and $7 \mathrm{~mm}$ in diameter), i.e. stage I, with DCIS. Both tumors were hormone receptor-positive. TAM was switched to TOR. At the most recent follow-up (10/2007, 33 months), the patient was well and had no evidence of recurrence. Neither patient had any family history of breast cancer, nor did they take medications associated with breast cancer risk. All laboratory values were within normal limits.

\section{Discussion}

We have experienced $8 \mathrm{MBC}$ cases in the last 4 years (table 1 ). The median age at diagnosis (66.6 years) is higher than that of female breast cancer patients. The rate of estrogen receptor (ER) positivity is also higher than in females. All serum estra- diol levels that we were able to measure were within normal range. Medical and family histories were unremarkable in both of our present cases (neither was examined for genes such as BRCA2). Among the 8 reported MBC cases, gynecomastia was found only in case 4 (table 1) and was bilateral. While $20-30 \%$ of MBC patients have gynecomastia in western countries, this is an infrequent finding in Japan, being seen in only $2.5 \%$ of MBC cases [1]. Fentiman et al. [2], Giordano et al. [3], and Rosen [4] warned that gynecomastia should not be regarded as a precancerous state.

Usually, 5 years of TAM is recommended as adjuvant therapy for early $\mathrm{MBC}[2,5,6]$. However, as yet, there has not been adequate research on aromatase inhibitor (AI) treatment for early MBC. On the other hand, the efficacy of AI for advanced and metastatic MBC is high according to several reports $[2,3]$, though it is less effective in male than in female cases. Men have fewer AI targets than women, suggesting that equivalent doses should be more effective in men. There is controversy regarding AI but we consider the differences in hormonal environments between men and women to be important, especially the higher androgen levels in men. Estrogen in men is synthesized from testosterone or its precursors by aromatase in adipose, testicular, and hepatic tissues. It is thought that levels of estradiol in $\mathrm{MBC}$ are no higher than those of healthy men [6]. However, aromatase activity is reportedly increased in tumoral and peritumoral tissues [7]. Moreover, this tendency was observed to be more marked in men than in women. Thus, the tumoral and peritumoral environments, which are high in estrogen, promote the growth of tumors which have ERs [8]. It is said that, in men on AI treatment, estrogen produced in the testes ( $20 \%$ of all estrogen) is not influenced by AI $[3,5,9]$. However, estrogen is also synthesized from testosterone which is impacted by aromatase. It seems unlikely that AI would not reach the testes. Therefore, we speculate that aromatase in the testes is also suppressed by AI. In men, there is generally much more testosterone than estrogen. Testosterone will greatly increase and estrogen will decrease when a man takes AI $[2,10]$. The possibility that an 
abundance of testosterone reduces AI efficacy, raises 3 hypothetical mechanisms. First, any surviving aromatase (especially peritumoral) would supply estrogen. Second, estrogen might be synthesized from testosterone by enzymes other than aromatase. Indeed, other enzymes have been identified in animal experiments, namely estrone sulfatase and 17ßHSD [7]. Third, testosterone itself might stimulate a tumor, either directly or indirectly, by other as yet unknown pathways. Testosterone must be a 'key' factor because orchiectomy is effective for MBC [2], and AI efficacy is higher in orchiectomized than in non-orchiectomized men [3]. The results of a major trial, currently underway using a gonadotropin-releasing hormone $(\mathrm{GnRH})$ analog with AI, are eagerly anticipated [5]. In men, it is thought that ER positivity does not contribute to prognosis as much as in women [5]. The hormonal environment is very different from that in women, including the processes supplying estrogen to tissues. Thus, different approaches are needed for MBC.

In our 2 bilateral nonsynchronous MBC cases, the second cancers developed during endocrine therapy with TAM. DCISs were observed long after treatment of the original tumors, indicating that they were primary tumors rather than recurrences [11]. Both patients have been on TOR since their second surgeries. We do not know whether TAM should have been switched to AI treatment considering that anti-estrogens had failed. With further investigation, it is hoped that both the indications and the optimal protocol for AI as adjuvant therapy will soon be clarified.

\section{References}

1 Matsuda M, Iwase T, Yoshimoto Y, Kasumi F, Akiyama F, Sakamoto G: Male breast cancer: clinicopathological features and time trends. Journal Jpn Practical Surgeon Soc 1997;58:513-518 (in Japanese with English abstract)

$>_{2}$ Fentiman IS, Fourquet A, Hortobagyi GN: Male breast cancer. Lancet 2006;367:595-604.

3 Giordano SH, Hortobagyi GN: Efficacy of anastrozole in male breast cancer. Am J Clin Oncol 2002;25:235-237.

4 Rosen PP: Gynecomastia: benign lesions of the male breast; in Rosen PP (ed): Rosen's Breast Pathology. New York, Lippincott Williams \& Wilkins, 2001, pp. 611.
5 Nahleh ZA: Hormonal therapy for MBC: a different approach for a different disease. Cancer Treat Rev 2006;32:101-105.

6 Lenfant-Pejovic MH, Mlika-Cabanne N, Bouchardy C, Auquier A: Risk factors for male breast cancer: a Franco-Swiss case-control study. Int J Cancer 1990;45:661-665.

7 Sasano H, Ozaki M: Aromatase expression and its localization in human breast cancer. J Steroid Biochem Molec Biol 1997;61:293-298.
8 Sasano H, Kimura M, Shizawa S, Kimura N, Nagura $\mathrm{H}$ : Aromatase and steroid receptors in gynecomastia and male breast carcinoma: an immunohistochemical study. J Clin Endocrinol Metab 1996;81: 3063-3067.

9 Handelsman DJ: Androgen action and pharmacologic uses. Endocrinology 2001;3:2232-2242.

10 Mauras N, O'Brien KO, Klein KO, Hayes V: Estrogen suppression in males: metabolic effects. J Clin Endocrinol Metab 2000;85:2370-2377.

11 Kasumi F: Bilateral breast carcinoma. Nippon Geka Gakkai Zasshi 1985;86:266-279 (in Japanese with English abstract). 